\title{
Carcinoma of the Conjunctiva Clinical Distant Metastasis TNM Finding v7
}

National Cancer Institute

\section{Source}

National Cancer Institute. Carcinoma of the Conjunctiva Clinical Distant Metastasis TNM

Finding v7. NCl Thesaurus. Code C88609.

A clinical finding about one or more characteristics of carcinoma of the conjunctiva,

following the rules of the TNM AJCC V7 classification system as they pertain to distant metastases. 